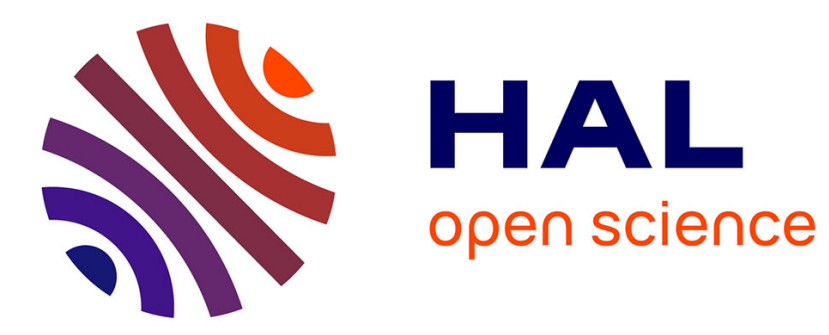

\title{
Guest Editorial Special Issue on Medical Imaging and Image Computing in Computational Physiology
}

Alejandro F. Frangi, D. Rod Hose, Peter J. Hunter, Nicholas Ayache, Dana

Brooks

\section{- To cite this version:}

Alejandro F. Frangi, D. Rod Hose, Peter J. Hunter, Nicholas Ayache, Dana Brooks. Guest Editorial Special Issue on Medical Imaging and Image Computing in Computational Physiology. IEEE Transactions on Medical Imaging, 2013, 32 (1), pp.1-7. 10.1109/TMI.2012.2234320 . hal-01355239

\section{HAL Id: hal-01355239 \\ https://inria.hal.science/hal-01355239}

Submitted on 22 Aug 2016

HAL is a multi-disciplinary open access archive for the deposit and dissemination of scientific research documents, whether they are published or not. The documents may come from teaching and research institutions in France or abroad, or from public or private research centers.
L'archive ouverte pluridisciplinaire HAL, est destinée au dépôt et à la diffusion de documents scientifiques de niveau recherche, publiés ou non, émanant des établissements d'enseignement et de recherche français ou étrangers, des laboratoires publics ou privés. 


\section{Editorial}

\section{Medical Imaging and Image Computing in Computational Physiology}

\section{INTRODUCTION}

A ccording to the STEP research roadmap (Fenner et al. 2008) the Virtual Physiological Human (VPH) is a methodological and technological framework that once established will enable the investigation of the human body as a single complex system. Underlying the VPH concept, the International Union for Physiological Sciences (IUPS) has been sponsoring for more than a decade now the IUPS Physiome Project (Bassingthwaighte et al. 2000, Hunter and Borg 2003), which is a worldwide public domain effort to provide a computational framework for understanding human physiology. It aims to develop integrative models at all levels of biological organization, from genes to the whole organism via gene regulatory networks, protein pathways, integrative cell function, and tissue and whole organ structure/function relations. Such an approach aims at transforming current practice in medicine and underpins a new era of computational medicine (Winslow et al. 2012).

In this context, medical imaging and image computing play, and will continue to play, an increasingly important role as they provide systems and methods to image, quantify and fuse both structural and functional information about the human being in vivo. These two broad research areas include the transformation of generic computational models to represent specific subjects, thus paving the way for personalized computational models (Ayache et al. 2005). Individualization of generic computational models through imaging can be realized in three complementary directions: $a$ ) definition of the subjectspecific computational domain (anatomy) and related subdomains (tissue types); $b$ ) definition of boundary and initial conditions from (dynamic) imaging; and $c$ ) characterization of structural and functional tissue properties. In addition, imaging also has a pivotal role in the evaluation and validation of such models both in humans and in animal models, and in the translation of such models to the clinical setting with both diagnostic and therapeutic applications. In this specific context, molecular, biological, and pre-clinical imaging render additional data and understanding of basic structure and function in molecules, cells, tissues and animal models that may be transferred to human physiology where appropriate.

The applications of image-based VPH/Physiome models in basic and clinical domains are vast. Broadly speaking, they promise to become new virtual imaging techniques. Effectively more, often non-observable, parameters will be imaged in silico based on the integration of observable but sometimes sparse and inconsistent multimodal images and physiological measurements. Computational models will serve to engender interpretation of the measurements in a way compliant with the underlying biophysical, biochemical or biological laws of the physiological or pathophysiological processes under investigation. Ultimately, such investigative tools and systems will help our understanding of disease processes, the natural history of disease evolution, and the influence on the course of a disease of pharmacological and/or interventional therapeutic procedures. Cross-fertilization between imaging and modeling goes beyond interpretation of measurements in a way consistent with physiology. Image-based patient-specific modeling, combined with models of medical devices and pharmacological therapies, opens the way to predictive imaging whereby one will be able to understand, plan and optimize such interventions in silico.

\section{SPECIAL ISSUE CONTENTS}

This special issue received 19 manuscripts from which 11 were accepted after thorough revision by three to four reviewers each. Additionally, a twelfth paper fitting the special issue was included from the accepted pool of regular submissions after consultation with the authors.

Although not by intention, and yet perhaps not so surprisingly, most of these papers are focused on various aspects of the cardiovascular system across various physiological processes and observational scales. Although progress has been made in Physiome research across virtually all organ systems (Slominany et al. 2004, van Essen et al. 2005, Walker et al. 2006, Liao et al. 2008, Halling-Brown et al. 2010, Li et al. 2010, Tawhai et al. 2011, Shim et al. 2011, Moss et al. 2012, Viceconti et al. 2012), the cardiovascular system is indeed perhaps the most developed, with the Cardiac Physiome Project being the first one to take off (Noble et al. 2012). Virtually all of these papers report on multi-group research collaborations, showing the cross-disciplinary and international nature of this research endeavor.

The first set of papers deals with image-based anatomical models and atlases of various structures at an exquisite level of detail. Aslanidi et al. present an experimental technique based on stained micro Computed Tomography (CT) images to construct very detailed atrial models of the canine heart. The proposed technique is able to image the Bachmann's bundle, the atrioventricular node, the pulmonary arteries and veins with clear inter-tissue contrast. In the paper by Zhao et al., the authors outline a suite of image processing tools that have been used to construct a high-resolution image-based model of $3 \mathrm{D}$ atrial anatomy, which incorporates realistic surface geometry and myofibre architecture. In Hoogendoorn et al., the authors present a detailed atlas and spatio-temporal statistical model of the human heart based on a large population of 3D+time multi-slice computed tomography sequences, along with the framework for construction of the atlas. The paper by Sebastian et al. proposes a model of the cardiac conduction system (CCS) based on structural information derived from stained calf tissue. The CCS model is based on L-systems grammars and is personalized based on a combination of subject-specific landmarks and population specific structural statistics. The paper by Goyal et al. develops a novel method to reconstruct 3D coronary vasculature from cryomicrotome images, comprised of two distinct sets of data - from fluorescent microsphere beads and coronary vasculature. 
The second set of papers focuses on personalized modeling of cardiac electrical activity or vascular flow dynamics. The paper by Krueger et al. presents a chain of tools that is an important step towards the use of detailed atrial models for patient-specific AF diagnosis and ablation therapy planning and thus their clinical translation. Ho, Mithraratne \& Hunter present a numerical simulation of detailed cerebral venous flow. While ample attention has been given to arterial cerebral flow dynamics and 1D, 2D and 3D models have been reported in the literature, this work is the first one in providing an anatomically accurate 3D model of cerebral venous return flow. In the subsequent paper, Ho et al. report on a 3D model and a 0D model for the flow analysis of trans jugular intrahepatic portosystemic shunt (TIPS), which induces drastic flow alterations in the liver. The proposed model is useful towards a theoretical understanding of TIPS procedures as well as to develop patient-specific planning systems that trade-off the risks inherent to the procedure with the urgency of relieving the patient from the pain associated with portal hypertension.

The third category of papers deals with computational methods for simulating medical imagery and incorporate knowledge of imaging physics and physiology/biophysics. These papers are important in that they enable the generation of gold-standard data for validating computational models and allow understanding of how physiology or biophysics affect image quality and appearance. The paper by Prakosa et al. proposes a new approach for the generation of synthetic but visually realistic time series of cardiac images based on an electromechanical model of the heart and real clinical $3 \mathrm{D}+$ time image sequences. Such databases of visually realistic images of controls and patients can be generated when the underlying cardiac motion and some biophysical parameters are known. Glatard et al. present the Virtual Imaging Platform (VIP), a platform accessible via the web to facilitate the sharing of object models and multimodality medical image simulators, and to provide access to distributed computing and storage resources. Such resources open exciting avenues for developing large databases of images with ground truth data to evaluate medical image analysis and modeling techniques.

Finally, the last two papers focus on models of virtual treatment of cerebral aneurysms and on assessing the quality of numerical meshes in cardiac simulations. The work by Morales et al. present a method based on dynamic path planning to model the distribution of embolization coils in cerebral aneurysms. The virtual coiling technique reproduces the macroscopic behavior of inserted coils and properly captures the densities, shapes and coil distributions inside aneurysm cavities. The method was used to assess local aneurysmal hemodynamics after coiling using computational fluid dynamics. Lamata et al. explored various mesh quality criteria for cardiac simulations. They make the point that generic geometrical quality metrics have limited success in predicting stability, and an analysis of the simulation problem may be required for an optimal definition of quality.

\section{FUTURE TRENDS AND CHALLENGES}

This special issue confirms the important progress made in the area of the cardiovascular system in terms of patient specific modeling. It has also shown that there is ample space for further research within and beyond this organ system. In par- ticular, we hope this special issue will help to anticipate the challenges and opportunities in personalized modeling of other organ systems where personalization and image-based modeling have had more limited penetration so far.

Without pretending to survey this area exhaustively, a number of future trends and challenges are highlighted here:

- Multiscale structural and functional biomedical imaging. Modeling progress is inherently tightly coupled to our ability to interpret new biomedical measurements and to gain new insights into basic biological and physiological mechanisms (Sharpe 2011). Clinical translation of models is limited by the ability to couple generic models to patientspecific data. Biomedical imaging, from nano- to macroscales is one of the fundamental experimental and clinical tools to gain physiological understanding or personalized predictions. The last decades have witnessed an enormous development of imaging techniques across observational scales; more recently, a number of articles have started to recognize the importance of multiscale multimodal imaging in various application domains in both biology and medicine (Tang et al. 2011, Chaurand et al. 2011, Goergen and Sosnovik 2011, Kim et al. 2012, Wang and Hu 2012, among many others). Other research avenues emphasize integrative image-based assessments of structure and function (Thilo et al. 2010, Gillies et al. 2010, Vasilescu et al. 2012). The challenge will now be to seamlessly integrate image information across nano-, meso- and macro- scales and to build further detailed multi-scale anatomo-functional models.

- Detailed multiscale anatomical modeling amenable for physiological modeling: the works of Hoogendoorn et al., Sebastian et al., Goyal et al. and Aslanidi et al. illustrate the value of different imaging modalities from micro to macro scales, to reconstruct various anatomical organ structures. Information across scales needs to be appropriately amalgamated both in terms of anatomy and physiology using computational models. In some cases, models can be informed from subject-specific imaging modalities but the work of Sebastian et al., Krueger et al. and Hoogendoorn et $a l$. also show how domain information can be used to produce generative models that fill in for missing individualized data by resourcing to generative rules based on anatomical or physiological knowledge further constrained by statistical information from relevant species or population data.

- From image databases to human development and disease progression models. The image analysis community has developed advanced techniques for building computational atlases of various organ systems (Miller and Qiu 2009, Young and Frangi 2009, Lombaert et al. 2012, Evans et al. 2012, Baldock and Burger 2012). More specifically, recent emphasis has been placed in terms of modeling human development (Kuklisova-Murgasova et al. 2011, Serag et al. 2012, Cleary et al. 2011) and disease progression (Mansi et al. 2011, Ardekani et al. 2009, Durrleman et al. 2012, Lorenzi et al. 2012) thus creating highly detailed spatiotemporal atlases. One of the challenges is to underpin current phenotypic generative models with biophysical and physiological principles (e.g. Schneider et al. 2012).

- Linking anatomically accurate biophysical models to omics data. VPH/Physiome models are sensu stricto multiscale models that link subcellular and cellular processes with tissue, organ and system levels. Some recent papers have 
started to recognize the need to link up omics scales with tissue and organ scales (Hawrylycz et al. 2012, Atkinson et al. 2011) in a spatially resolved fashion. Future research will seek to inform, with omics data, anatomically and physiologically accurate multiscale models and gain insights into their relative role in health and disease.

- Image-based estimation of patient-specific in vivo tissue properties. Measurement techniques, which are not primarily designed to produce images, such as electroencephalography (EEG), electrocardiography (EKG), and others, but which produce data susceptible to be represented as maps (i.e., containing positional information), can be seen as forms of medical imaging. Estimation of tissue properties or model parameters from state-of-the-art medical imagery or anatomically localized multidimensional signals is fundamental for model personalization and clinical applications (Sermesant et al. 2012). To this end, new data assimilation techniques are emerging (Sermesant et al. 2006, Chinchapatnam et al. 2008, Delingette et al. 2012, Marchesseau et al. 2012, Chabiniok et al. 2012, Vidal et al. 2012, Chapelle et al., Moireau et al.) some of which account for modeling and measuring uncertainties (Konukoglu et al. 2011).

- Non-invasive imaging of physiological properties through biophysical modeling. Closely connected to the previous challenge, the combination of imaging and personalized modeling enables virtual imaging techniques, viz. imaging of non-directly measurable physiological information. Examples of such techniques are cardiac electrophysiology (Wang et al. 2010, 2011), vascular flows in aneurysms (Cebral et al. 2005, Geers et al. 2011, Rayz et al. 2007) and stenosis (Cebral et al. 2002, Groen et al. 2010), cardiac and coronary hemodynamics (Lee and Smith 2012, Mihalef et al. 2012), bone mechanical stresses and remodeling (Paoletti et al. 2012), among others.

- Image-based and patient-specific virtual treatment modeling for interventional planning. The work by Morales et al. showed how the combination of device modeling and virtual deployment, in addition to patient-specific image-based anatomical modeling, can help to carry out patient-specific treatment plans and assess alternative therapeutic strategies. Although a number of such approaches have already been introduced in the literature (Wang et al. 2012, Sankaran et al. 2012, Mansi et al. 2012, Niederer et al. 2012, Larrabide et al. 2012a, Orlowski et al. 2012, Zheng et al.), further research efforts will be invested in modeling devices and interventions as well as the interplay between the devices and relevant biological processes (Jolley et al.2008, Jolley et al.2010, Vairo et al. 2010, Xu et a. 2011, Xu et al. 2012).

- Integration and fusion of multimodal imaging and multidimensional physiological signals for model personalization. The distinction between imaging and multidimensional signals becomes less and less essential in the context of biophysical and physiological model personalization and, indeed, from a clinical point of view both approaches provide complementary information of individuals. Physiological signals, particularly those obtained through seamless sensing through wearable or home monitoring (Chan et al. 2012, Farina et al. 2012, Triantafyllidis et al. 2012, Yang and Hsu 2012) and those obtained through invasive interventional sensors (Miri et al. 2010, Weber et al. 2011, Viceconti et al. 2011, Porras et al.) can provide essential information to personalized models (Fer-
nández-Peruchena and Prado-Velasco 2010). The former, contribute relevant information on the biorhythms, lifestyle or environmental factors from patients while the latter provide information on the immediate physiological response to specific therapeutic actions thus enabling therapy optimization during delivery.

- Image-based modeling frameworks and standards. As the paradigm behind the Physiome and the VPH gains widespread acceptance in the scientific domain, there is an urgent requirement to demonstrate its translational value into the clinics and its adoption by industry. Focusing in the specific area of image-based modeling, a number of toolkits ${ }^{1}$ have been developed to facilitate the task of building both patient-specific image-based models (Wolf et al. 2005, Bitter et al. 2007, Viceconti et al. 2007, MacLeod et $a l$. 2009) and for clinical prototyping of image-based modeling tools (Larrabide et al. 2012b). Such image-based modeling frameworks are complementary to the various simulation tools available within the VPH Toolkit (Cooper et al. 2010, Garny et al. 2010, Bradley et al. 2011) and, in some cases, are part of it. Additionally, a number of markup language standards are being developed (Beard et al. 2009, Christie et al. 2009, Waltemath et al. 2011) that will be crucial for addressing some of the challenges associated with multiscale and multiphysics coupling multimodal data and computational models. Specifically, new modeling frameworks and standards will have to address parameter and model uncertainty (Miller et al. 2012) and their propagation to simulation outcomes.

All in all, there are many opportunities for advanced biomedical imaging and biomedical image computing research in relationship with integrative physiological modeling. In this arena, our community will undoubtedly contribute to and witness a research expansion in terms of new methodologies and image-enabled physiological insights in the years to come.

\section{ACKNOWLEDGEMENTS}

The Guest Editors would like to again acknowledge the constant support received from Dr. Honghai Zhang, Editorial Officer and the help of Dr Alan Garny who provided comments on the manuscript of this editorial.

\section{REFERENCES}

Ardekani S, Weiss RG, Lardo AC, George RT, Lima JA, Wu KC, Miller MI, Winslow RL, Younes L. Computational method for identifying and quantifying shape features of human left ventricular remodeling. Ann Biomed Eng. 2009 Jun;37(6):1043-54.

Atkinson A, Inada S, Li J, Tellez JO, Yanni J, Sleiman R, Allah EA, Anderson RH, Zhang H, Boyett MR, Dobrzynski H. Anatomical and molecular mapping of the left and right ventricular His-Purkinje conduction networks. J Mol Cell Cardiol. 2011 Nov;51(5):689-701.

Ayache N, Boissel J-P, Brunak S, Clapworthy G, Lonsdale G, Fingberg J, Frangi A, Deco G, Hunter P, Nielsen P, Halstead M, Hose R, Magnin I, Martin-Sanchez F, Sloot P, Kaandorp J, Hoekstra A, Van Sint Jan S, Viceconti M. Towards virtual physiological human: Multilevel modelling and simulation of the human anatomy and physiology. White paper - Edited by Directorate General INFSO \& Directorate General JRC - November 2005.

\footnotetext{
${ }^{1}$ A number of image-based modelling frameworks supporting complementary or specialised functionality have been developed over the last few years: cmGUI (www.physiomeproject.org), GIMIAS (www.gimias.org), MedINRIA (med.inria.fr), SCIRun (www.scirun.org), MAF (www.openmaf.org), Slicer (www.slicer.org), etc. Interoperability efforts have taken place within the CTK Consortium (www.commontk.org).
} 
http://ec.europa.eu/information_society/activities/health/docs/events/barcel ona2005/ec-vph-white-paper2005nov.pdf

Baldock RA, Burger A. Biomedical atlases: systematics, informatics and analysis. Adv Exp Med Biol. 2012;736:655-77.

Bassingthwaighte JB. Strategies for the physiome project. Ann Biomed Eng. 2000 Aug;28(8):1043-58.

Beard DA, Britten R, Cooling MT, Garny A, Halstead MD, Hunter PJ, Lawson J, Lloyd CM, Marsh J, Miller A, Nickerson DP, Nielsen PM, Nomura T, Subramanium S, Wimalaratne SM, Yu T. CellML metadata standards, associated tools and repositories. Philos Transact A Math Phys Eng Sci. 2009 May 28;367(1895):1845-67.

Bitter I, Van Uitert R, Wolf I, Ibáñez L, Kuhnigk JM. Comparison of four freely available frameworks for image processing and visualization that use ITK. IEEE Trans Vis Comput Graph. 2007 May-Jun;13(3):483-93.

Bradley C, Bowery A, Britten R, Budelmann V, Camara O, Christie R, Cookson A, Frangi AF, Gamage TB, Heidlauf T, Krittian S, Ladd D, Little C, Mithraratne K, Nash M, Nickerson D, Nielsen P, Nordb $\varnothing$ O, Omholt S, Pashaei A, Paterson D, Rajagopal V, Reeve A, Röhrle O, Safaei S, Sebastián R, Steghöfer M, Wu T, Yu T, Zhang H, Hunter PJ. OpenCMISS: a multiphysics \& multi-scale computational infrastructure for the VPH/Physiome project. Prog Biophys Mol Biol. 2011 Oct;107(1):32-47. Epub 2011 Jul 7.

Cebral JR, Castro MA, Appanaboyina S, Putman CM, Millan D, Frangi AF. Efficient pipeline for image-based patient-specific analysis of cerebral aneurysm hemodynamics: technique and sensitivity. IEEE Trans Med Imaging. $2005 \mathrm{Apr} ; 24(4): 457-67$.

Cebral JR, Yim PJ, Löhner R, Soto O, Choyke PL. Blood flow modeling in carotid arteries with computational fluid dynamics and MR imaging. Acad Radiol. 2002 Nov;9(11):1286-99.

Chabiniok R, Moireau P, Lesault PF, Rahmouni A, Deux JF, Chapelle D. Estimation of tissue contractility from cardiac cine-MRI using a biomechanical heart model. Biomech Model Mechanobiol. 2012 May;11(5):60930.

Chan M, Estève D, Fourniols JY, Escriba C, Campo E. Smart wearable systems: Current status and future challenges. Artif Intell Med, 2012 Nov 56(3);137-156.

Chapelle D, Fragu M, Mallet V, Moireau P.Fundamental principles of data assimilation underlying the Verdandi library: applications to biophysical model personalization within euHeart. Med Biol Eng Comput, in press.

Chaurand P, Cornett DS, Angel PM, Caprioli RM. From whole-body sections down to cellular level, multiscale imaging of phospholipids by MALDI mass spectrometry. Mol Cell Proteomics. 2011 Feb;10(2):O110.004259

Chinchapatnam P, Rhode KS, Ginks M, Rinaldi CA, Lambiase P, Razavi R, Arridge S, Sermesant M. Model-based imaging of cardiac apparent conductivity and local conduction velocity for diagnosis and planning of therapy. IEEE Trans Med Imaging. 2008 Nov;27(11):1631-42.

Christie GR, Nielsen PM, Blackett SA, Bradley CP, Hunter PJ. FieldML: concepts and implementation. Philos Transact A Math Phys Eng Sci. 2009 May 28;367(1895):1869-84

Cleary JO, Modat M, Norris FC, Price AN, Jayakody SA, Martinez-Barbera JP, Greene ND, Hawkes DJ, Ordidge RJ, Scambler PJ, Ourselin S, Lythgoe MF. Magnetic resonance virtual histology for embryos: 3D atlases for automated high-throughput phenotyping. Neuroimage. 2011 Jan 15;54(2):769-78

Cooper J, Cervenansky F, De Fabritiis G, Fenner J, Friboulet D, Giorgino T, Manos S, Martelli Y, Villà-Freixa J, Zasada S, Lloyd S, McCormack K, Coveney PV. The Virtual Physiological Human ToolKit. Philos Transact A Math Phys Eng Sci. 2010 Aug 28;368(1925):3925-36.

Delingette H, Billet F, Wong KC, Sermesant M, Rhode K, Ginks M, Rinaldi CA, Razavi R, Ayache N. Personalization of cardiac motion and contractility from images using variational data assimilation. IEEE Trans Biomed Eng. 2012 Jan;59(1):20-4.

Durrleman S, Pennec X, Trouvé A, Ayache N, Braga J. Comparison of the endocranial ontogenies between chimpanzees and bonobos via temporal regression and spatiotemporal registration. J Hum Evol. 2012 Jan;62(1):74-88

Evans AC, Janke AL, Collins DL, Baillet S. Brain templates and atlases. Neuroimage. 2012 Aug 15;62(2):911-22.

Farina D, Cianca E, Marchetti N, Frattasi S. Special issue: Wearable computing and communication for e-Health. Med Biol Eng Comput. 2012 Nov;50(11):1117-8

Fenner JW, Brook B, Clapworthy G, Coveney PV, Feipel V, Gregersen H, Hose DR, Kohl P, Lawford P, McCormack KM, Pinney D, Thomas SR, Van Sint Jan S, Waters S, Viceconti M. The EuroPhysiome, STEP and a roadmap for the virtual physiological human. Philos Transact A Math Phys Eng Sci. 2008 Sep 13;366(1878):2979-99.

Fernández-Peruchena CM, Prado-Velasco M. Smart sensors and virtual physiology human approach as a basis of personalized therapies in diabetes mellitus. Open Biomed Eng J. 2010;4:236-49.
Garny A, Cooper J, Hunter PJ. Toward a VPH/Physiome ToolKit. Wiley Interdiscip Rev Syst Biol Med. 2010 Mar-Apr;2(2):134-47

Geers AJ, Larrabide I, Radaelli AG, Bogunovic H, Kim M, Gratama van Andel HA, Majoie CB, VanBavel E, Frangi AF. Patient-specific computational hemodynamics of intracranial aneurysms from 3D rotational angiography and CT angiography: an in vivo reproducibility study. AJNR Am J Neuroradiol. 2011 Mar;32(3):581-6.

Gillies RJ, Anderson AR, Gatenby RA, Morse DL. The biology underlying molecular imaging in oncology: from genome to anatome and back again. Clin Radiol. 2010 Jul;65(7):517-21.

Goergen CJ, Sosnovik DE. From molecules to myofibers: multiscale imaging of the myocardium. J Cardiovasc Transl Res. 2011 Aug;4(4):493-503

Groen HC, Simons L, van den Bouwhuijsen QJ, Bosboom EM, Gijsen FJ, van der Giessen AG, van de Vosse FN, Hofman A, van der Steen AF, Witteman JC, van der Lugt A, Wentzel JJ. MRI-based quantification of outflow boundary conditions for computational fluid dynamics of stenosed human carotid arteries. J Biomech. 2010 Aug 26;43(12):2332-8.

Halling-Brown M, Pappalardo F, Rapin N, Zhang P, Alemani D, Emerson A, Castiglione F, Duroux P, Pennisi M, Miotto O, Churchill D, Rossi E, Moss DS, Sansom CE, Bernaschi M, Lefranc MP, Brunak S, Lund O, Motta S, Lollini PL, Murgo A, Palladini A, Basford KE, Brusic V, Shepherd AJ. ImmunoGrid: towards agent-based simulations of the human immune system at a natural scale. Philos Transact A Math Phys Eng Sci. 2010 Jun 13;368(1920):2799-815.

Hawrylycz MJ, Lein ES, Guillozet-Bongaarts AL, Shen EH, Ng L, Miller JA, van de Lagemaat LN, Smith KA, Ebbert A, Riley ZL, Abajian C, Beckmann CF, Bernard A, Bertagnolli D, Boe AF, Cartagena PM, Chakravarty MM, Chapin M, Chong J, Dalley RA, Daly BD, Dang C, Datta S, Dee N, Dolbeare TA, Faber V, Feng D, Fowler DR, Goldy J, Gregor BW, Haradon Z, Haynor DR, Hohmann JG, Horvath S, Howard RE, Jeromin A, Jochim JM, Kinnunen M, Lau C, Lazarz ET, Lee C, Lemon TA, Li L, Li Y, Morris JA, Overly CC, Parker PD, Parry SE, Reding M, Royall JJ, Schulkin J, Sequeira PA, Slaughterbeck CR, Smith SC, Sodt AJ, Sunkin SM, Swanson BE, Vawter MP, Williams D, Wohnoutka P, Zielke HR, Geschwind DH, Hof PR, Smith SM, Koch C, Grant SG, Jones AR. An anatomically comprehensive atlas of the adult human brain transcriptome. Nature. 2012 Sep 20;489(7416):391-9.

Hunter PJ, Borg TK. Integration from proteins to organs: the Physiome Project. Nat Rev Mol Cell Biol. 2003 Mar;4(3):237-43.

Jolley M, Stinstra J, Pieper S, Macleod R, Brooks DH, Cecchin F, Triedman JK. A computer modeling tool for comparing novel ICD electrode orientations in children and adults. Heart Rhythm. 2008 Apr;5(4):565-72

Jolley M, Stinstra J, Tate J, Pieper S, Macleod R, Chu L, Wang P, Triedman JK. Finite element modeling of subcutaneous implantable defibrillator electrodes in an adult torso. Heart Rhythm. 2010 May;7(5):692-8.

Kim E, Stamatelos S, Cebulla J, Bhujwalla ZM, Popel AS, Pathak AP. Multiscale imaging and computational modeling of blood flow in the tumor vasculature. Ann Biomed Eng. 2012 Nov;40(11):2425-41

Konukoglu E, Relan J, Cilingir U, Menze BH, Chinchapatnam P, Jadidi A, Cochet H, Hocini M, Delingette H, Jaïs P, Haïssaguerre M, Ayache N, Sermesant M. Efficient probabilistic model personalization integrating uncertainty on data and parameters: Application to eikonal-diffusion models in cardiac electrophysiology. Prog Biophys Mol Biol. 2011 Oct;107(1):

Kuklisova-Murgasova M, Aljabar P, Srinivasan L, Counsell SJ, Doria V, Serag A, Gousias IS, Boardman JP, Rutherford MA, Edwards AD, Hajnal JV, Rueckert D. A dynamic 4D probabilistic atlas of the developing brain. Neuroimage. 2011 Feb 14;54(4):2750-63.

Larrabide I, Kim M, Augsburger L, Villa-Uriol MC, Rüfenacht D, Frangi AF. Fast virtual deployment of self-expandable stents: method and in vitro evaluation for intracranial aneurysmal stenting. Med Image Anal. 2012 Apr;16(3):721-30.

Larrabide I, Villa-Uriol MC, Cárdenes R, Barbarito V, Carotenuto L, Geers AJ, Morales HG, Pozo JM, Mazzeo MD, Bogunović H, Omedas P, Riccobene C, Macho JM, Frangi AF. AngioLab-A software tool for morphological analysis and endovascular treatment planning of intracranial aneurysms. Comput Methods Programs Biomed. 2012 Nov;108(2):806-19.

Lee J, Smith NP. The multi-scale modelling of coronary blood flow. Ann Biomed Eng. 2012 Nov;40(11):2399-413.

Li X, Kruger JA, Nash MP, Nielsen PM. Modeling childbirth: elucidating the mechanisms of labor. Wiley Interdiscip Rev Syst Biol Med. 2010 JulAug;2(4):460-70

Liao D, Lelic D, Gao F, Drewes AM, Gregersen H. Biomechanical functional and sensory modelling of the gastrointestinal tract. Philos Transact A Math Phys Eng Sci. 2008 Sep 28;366(1879):3281-99.

Lombaert H, Peyrat JM, Croisille P, Rapacchi S, Fanton L, Cheriet F, Clarysse $\mathrm{P}$, Magnin I, Delingette H, Ayache N. Human atlas of the cardiac fiber architecture: study on a healthy population. IEEE Trans Med Imaging. 2012 Jul;31(7):1436-47. 
Lorenzi M, Ayache N, Pennec X. Regional flux analysis of longitudinal atrophy in Alzheimer's disease. Med Image Comput Comput Assist Interv. LNCS 2012;7510:739-746.

MacLeod RS, Stinstra JG, Lew S, Whitaker RT, Swenson DJ, Cole MJ, Krüger J, Brooks DH, Johnson CR. Subject-specific, multiscale simulation of electrophysiology: a software pipeline for image-based models and application examples. Philos Transact A Math Phys Eng Sci. 2009 Jun 13;367(1896):2293-310.

Mansi T, Voigt I, Georgescu B, Zheng X, Mengue EA, Hackl M, Ionasec RI, Noack T, Seeburger J, Comaniciu D. An integrated framework for finiteelement modeling of mitral valve biomechanics from medical images: application to MitralClip intervention planning. Med Image Anal. 2012 Oct;16(7):1330-46.

Mansi T, Voigt I, Leonardi B, Pennec X, Durrleman S, Sermesant M, Delingette $\mathrm{H}$, Taylor AM, Boudjemline Y, Pongiglione G, Ayache N. A statistical model for quantification and prediction of cardiac remodelling: application to tetralogy of Fallot. IEEE Trans Med Imaging. 2011 Sep;30(9):1605-16

Marchesseau S, Delingette H, Sermesant M, Ayache N.Fast parameter calibration of a cardiac electromechanical model from medical images based on the unscented transform. Biomech Model Mechanobiol. 2012, in press.

Mihalef V, Ionasec RI, Sharma P, Georgescu B, Voigt I, Suehling M, Comaniciu D. Patient-specific modelling of whole heart anatomy, dynamics and haemodynamics from four-dimensional cardiac CT images. Interface Focus. 2011 Jun 6;1(3):286-96.

Miller AK, Britten RD, Nielsen PM. Declarative representation of uncertainty in mathematical models. PLoS One. 2012;7(7):e39721. Epub 2012 Jul 3.

Miller MI, Qiu A. The emerging discipline of Computational Functional Anatomy. Neuroimage. 2009 Mar;45(1 Suppl):S16-39.

Miri R, Graf IM, Bayarri JV, Dössel O. Applicability of body surface potential map in computerized optimization of biventricular pacing. Ann Biomed Eng. 2010 Mar;38(3):865-75. E

Moireau P, Bertoglio C, Xiao N, Figueroa CA, Taylor CA, Chapelle D, Gerbeau JF. Sequential identification of boundary support parameters in a fluid-structure vascular model using patient image data. Biomech Model Mechanobiol, in press.

Moss R, Grosse T, Marchant I, Lassau N, Gueyffier F, Thomas SR. Virtual patients and sensitivity analysis of the Guyton model of blood pressure regulation: towards individualized models of whole-body physiology. PLoS Comput Biol. 2012;8(6):e1002571.

Niederer SA, Shetty AK, Plank G, Bostock J, Razavi R, Smith NP, Rinaldi CA. Biophysical modeling to simulate the response to multisite left ventricular stimulation using a quadripolar pacing lead. Pacing Clin Electrophysiol. 2012 Feb;35(2):204-14

Noble D, Garny A, Noble PJ. How the Hodgkin-Huxley equations inspired the Cardiac Physiome Project. J Physiol. 2012 Jun 1;590(Pt 11):2613-28

Orlowski P, Summers P, Noble JA, Byrne J, Ventikos Y. Computational modelling for the embolization of brain arteriovenous malformations. Med Eng Phys. 2012 Sep;34(7):873-81

Paoletti N, Liò P, Merelli E, Viceconti M. Multilevel computational modeling and quantitative analysis of bone remodeling. IEEE/ACM Trans Comput Biol Bioinform. 2012 Sep-Oct;9(5):1366-78

Porras AR, Piella G, Berruezo A, Hoogendoorn C, Andreu D, FernandezArmenta J, Sitges M, Frangi AF. Interventional endocardial motion estimation from electro-anatomical mapping data: Application to scar characterization, IEEE Trans Biomed Eng, in press.

Rayz VL, Boussel L, Acevedo-Bolton G, Martin AJ, Young WL, Lawton MT, Higashida R, Saloner D. Numerical simulations of flow in cerebral aneurysms: comparison of CFD results and in vivo MRI measurements. J Biomech Eng. 2008 Oct;130(5):051011.

Sankaran S, Esmaily Moghadam M, Kahn AM, Tseng EE, Guccione JM, Marsden AL. Patient-specific multiscale modeling of blood flow for coronary artery bypass graft surgery. Ann Biomed Eng. 2012 Oct;40(10):222842.

Schneider M, Reichold J, Weber B, Székely G, Hirsch S. Tissue metabolism driven arterial tree generation. Med Image Anal. 2012 Oct;16(7):1397-414

Serag A, Aljabar P, Ball G, Counsell SJ, Boardman JP, Rutherford MA, Edwards $\mathrm{AD}$, Hajnal JV, Rueckert D. Construction of a consistent highdefinition spatio-temporal atlas of the developing brain using adaptive kernel regression. Neuroimage. 2012 Feb 1;59(3):2255-65. Erratum in: Neuroimage. 2012 Nov 1;63(2):998.

Sermesant M, Chabiniok R, Chinchapatnam P, Mansi T, Billet F, Moireau P, Peyrat JM, Wong K, Relan J, Rhode K, Ginks M, Lambiase P, Delingette H, Sorine M, Rinaldi CA, Chapelle D, Razavi R, Ayache N. Patientspecific electromechanical models of the heart for the prediction of pacing acute effects in CRT: a preliminary clinical validation. Med Image Anal. 2012 Jan;16(1):201-15

Sermesant M, Moireau P, Camara O, Sainte-Marie J, Andriantsimiavona R, Cimrman R, Hill DL, Chapelle D, Razavi R. Cardiac function estimation from MRI using a heart model and data assimilation: advances and difficulties. Med Image Anal. 2006 Aug;10(4):642-56.

Sharpe J. Two ways to use imaging: focusing directly on mechanism, or indirectly via behaviour? Curr Opin Genet Dev. 2011 Oct;21(5):523-9.

Shim VB, Hunter PJ, Pivonka P, Fernandez JW. A multiscale framework based on the physiome markup languages for exploring the initiation of osteoarthritis at the bone-cartilage interface. IEEE Trans Biomed Eng. 2011 Dec;58(12):3532-6.

Slomiany A, Sano S, Grabska M, Yamaki K, Slomiany BL. Gastric mucosal cell homeostatic physiome. Critical role of ER-initiated membranes restitution in the fidelity of cell function renewal. J Physiol Pharmacol. 2004 Dec;55(4):837-60.

Tang S, Zhou Y, Chan KK, Lai T. Multiscale multimodal imaging with multiphoton microscopy and optical coherence tomography. Opt Lett. 2011 Dec 15;36(24):4800-2

Tawhai M, Clark A, Donovan G, Burrowes K. Computational modeling of airway and pulmonary vascular structure and function: development of a "lung physiome". Crit Rev Biomed Eng. 2011;39(4):319-36

Thilo C, Hanley M, Bastarrika G, Ruzsics B, Schoepf UJ. Integrative computed tomographic imaging of cardiac structure, function, perfusion, and viability. Cardiol Rev. 2010 Sep-Oct;18(5):219-29.

Triantafyllidis A, Koutkias V, Chouvarda I, Maglaveras N. A Pervasive Health System Integrating Patient Monitoring, Status Logging and Social Sharing. IEEE Trans Inf Technol Biomed, in press.

Vairo G, Cioffi M, Cottone R, Dubini G, Migliavacca F. Drug release from coronary eluting stents: A multidomain approach. J Biomech. 2010 May 28;43(8):1580-9.

van Essen NL, Anderson IA, Hunter PJ, Carman J, Clarke RD, Pullan AJ. Anatomically based modelling of the human skull and jaw. Cells Tissues Organs. 2005;180(1):44-53.

Vasilescu DM, Gao Z, Saha PK, Yin L, Wang G, Haefeli-Bleuer B, Ochs M, Weibel ER, Hoffman EA. Assessment of morphometry of pulmonary acini in mouse lungs by nondestructive imaging using multiscale microcomputed tomography. Proc Natl Acad Sci U S A. 2012 Oct 16;109(42):17105-10

Viceconti M, Clapworthy G, Testi D, Taddei F, McFarlane N. Multimodal fusion of biomedical data at different temporal and dimensional scales. Comput Methods Programs Biomed. 2011 Jun;102(3):227-37.

Viceconti M, Taddei F, Cristofolini L, Martelli S, Falcinelli C, Schileo E. Are spontaneous fractures possible? An example of clinical application for personalised, multiscale neuro-musculo-skeletal modelling. J Biomech. 2012 Feb 2;45(3):421-6

Viceconti M, Zannoni C, Testi D, Petrone M, Perticoni S, Quadrani P, Taddei F, Imboden S, Clapworthy G. The multimod application framework: a rapid application development tool for computer aided medicine. Comput Methods Programs Biomed. 2007 Feb;85(2):138-51

Vidal FP, Villard PF, Lutton E. Tuning of patient-specific deformable models using an adaptive evolutionary optimization strategy. IEEE Trans Biomed Eng. 2012 Oct;59(10):2942-9.

Walker D, Wood S, Southgate J, Holcombe M, Smallwood R. An integrated agent-mathematical model of the effect of intercellular signalling via the epidermal growth factor receptor on cell proliferation. J Theor Biol. 2006 Oct 7;242(3):774-89.

Waltemath D, Adams R, Bergmann FT, Hucka M, Kolpakov F, Miller AK, Moraru II, Nickerson D, Sahle S, Snoep JL, Le Novère N. Reproducible computational biology experiments with SED-ML--the Simulation Experiment Description Markup Language. BMC Syst Biol. 2011 Dec 15;5:198.

Wang L, Wong KC, Zhang H, Liu H, Shi P. Noninvasive computational imaging of cardiac electrophysiology for 3-D infarct detection and quantitation. IEEE Trans Biomed Eng. 2011 Apr;58(4):1033-43.

Wang L, Zhang H, Wong KC, Liu H, Shi P. Physiological-model-constrained noninvasive reconstruction of volumetric myocardial transmembrane potentials. IEEE Trans Biomed Eng. 2010 Feb;57(2):296-315.

Wang LV, Hu S. Photoacoustic tomography: in vivo imaging from organelles to organs. Science. 2012 Mar 23;335(6075):1458-62.

Wang Q, Sirois E, Sun W. Patient-specific modeling of biomechanical interaction in transcatheter aortic valve deployment. J Biomech. $2012 \mathrm{Jul}$ 26;45(11):1965-71.

Weber FM, Luik A, Schilling C, Seemann G, Krueger MW, Lorenz C, Schmitt $\mathrm{C}$, Dossel O. Conduction velocity restitution of the human atrium- an efficient measurement protocol for clinical electrophysiological studies. IEEE Trans Biomed Eng. 2011 Sep;58(9):2648-55

Winslow RL, Trayanova N, Geman D, Miller MI. Computational medicine: translating models to clinical care. Sci Transl Med. 2012 Oct 31;4(158):158rv11.

Wolf I, Vetter M, Wegner I, Böttger T, Nolden M, Schöbinger M, Hastenteufel M, Kunert T, Meinzer HP. The medical imaging interaction toolkit. Med Image Anal. 2005 Dec;9(6):594-604 
Xu Z, Kamocka M, Alber M, Rosen ED. Computational approaches to studying thrombus development. Arterioscler Thromb Vasc Biol. 2011 Mar;31(3):500-5.

Xu Z, Kim O, Kamocka M, Rosen ED, Alber M. Multiscale models of thrombogenesis. Wiley Interdiscip Rev Syst Biol Med. 2012 May-Jun;4(3):23746.

Yang CC, Hsu YL. A review of accelerometry-based wearable motion detectors for physical activity monitoring. Sensors (Basel). 2010;10(8):7772-88.

Young A.A., Frangi A.F. Computational cardiac atlases: from patient to population and back. Exp Physiol. 2009 May;94(5):578-96.

Zheng Y, John M, Liao R, Nottling A, Boese J, Kempfert J, Walther T, Brockmann G, Comaniciu D. Automatic Aorta Segmentation and Valve Landmark Detection in C-Arm CT for Transcatheter Aortic Valve Implantation. IEEE Trans Med Imaging, in press.

\section{FURTHER READING}

Coatrieux J.-L., Bassingthwaighte J.B. 2006 On the Physiome and Beyond, Proceedings of the IEEE, 2006; 94(4):671-677.

Coatrieux JL, Frangi AF, Peng GC, D'Argenio DZ, Marmarelis VZ, Michailova A. Editorial: TBME Letters special issue on multiscale modeling and analysis in computational biology and medicine-Part-2. IEEE Trans Biomed Eng. 2011 Dec;58(12):3434-9.

Frangi AF, Coatrieux JL, Peng GC, D'Argenio DZ, Marmarelis VZ, Michailova A. Editorial: TBME Letters special issue on multiscale modeling and analysis in computational biology and medicine-Part-1. IEEE Trans Biomed Eng. 2011 Oct;58(10):2936-42.

Garny A., Cooper J., Hunter P.J. 2010. Toward a VPH/Physiome ToolKit. Wiley Interdiscip Rev Syst Biol Med. 2010;2(2):134-47.

Gavaghan, D., Coveney, P.V., Kohl, P. 2009 The virtual physiological human: tools and applications I. Phil. Trans. R. Soc. A 367, 1817-1821.

Han D., Liu Q., Luo Q 2009 China Physiome Project: A Comprehensive Framework for Anatomical and Physiological Databases From the China Digital Human and the Visible Rat, Proceedings of the IEEE, 2009;97(12):1969-76.

Hunter P.J., Coveney P.V., de Bono B., Diaz-Zuccarini V., Fenner J., Frangi A.F., Harris P., Hose D.R., Kohl P., Lawford P.V., McCormack K., Mendes M., Omholt S., Quarteroni A., Skår J., Tegner J., Thomas R.S., Tollis I., Tsamardinos I., van Beek J.H., Viceconti M. 2010 A vision and strategy for the virtual physiological human in 2010 and beyond. Phil. Trans. R. Soc. A 368, 2595-2614.

Hunter, P. J., Viceconti, M. 2009 The VPH-Physiome Project: Standards and Tools for Multiscale Modeling in Clinical Applications, IEEE Reviews in Biomedical Engineering, 2009;2:40-53.

White, R.J. Peng, G.C.Y. Demir, S.S. Multiscale modeling of biomedical, biological, and behavioral systems (Part 1), IEEE Engineering in Medicine and Biology Magazine, March/April 2009; 28(2):12-13.

White, R.J., Peng, G.C.Y., Demir, S.S. Multiscale modeling of biomedical, biological, and behavioral systems (Part 2), IEEE Engineering in Medicine and Biology Magazine, May/June 2009;28(3):8-9.

Yu T., Lloyd C.M., Nickerson D.P., Cooling M.T., Miller A.K., Garny A., Terkildsen J.R., Lawson J, Britten RD, Hunter PJ, Nielsen PM. 2011 The Physiome Model Repository 2. Bioinformatics. 1;27(5):743-4.

Yuan Y., Qi L., Luo S. 2008 The reconstruction and application of virtual Chinese human female. Comput Methods Programs Biomed. 2008;92(3):249-56.
NichOlas AYACHE, Guest Editor INRIA Sophia-Antipolis Sophia-Antipolis, France nicholas.ayache@inria.fr

DANA BROOKS, Guest Editor Northeastern University Boston, MA, USA brooks@ece.neu.edu

AlEJANDRO F. FRANGI, Guest Editor The University of Sheffield Sheffield, United Kingdom a.frangi@sheffield.ac.uk

D. Rod Hose, Guest Editor The University of Sheffield Sheffield, United Kingdom d.r.hose@sheffield.ac.uk

Peter J. Hunter, Guest Editor University of Auckland Auckland, New Zealand p.hunter@auckland.ac.nz 